\title{
Attempting Return: Iraqis' Remigration from Iraq
}

\author{
VANESSA IARIA
}

\begin{abstract}
The voluntary repatriation of refugees and internally displaced persons is interpreted as evidence of restored security and political stability, improved civil-state relations, and public confidence in reconstruction efforts in war-torn countries. The findings presented in this article indicate that Iraqi refugees' decision to return is driven less by improvements in Iraq than by their desire to rebuild their lives back home and overcome the difficult legal and socio-economic conditions in neighbouring countries. The article explores Iraqi returnees' experiences based on accounts of their return and subsequent remigration to Syria and Jordan. The micro- and macrotransformations occurring in post-Saddam Iraq have a strong bearing on refugees' return and reintegration in their home communities. In the absence of permanent solutions to protracted displacement, the Iraqis engage in transnational mobility and livelihood strategies and participate in the socio-economic developments in home and host countries through the constant multidirectional flow of economic, social, and human capital.
\end{abstract}

\section{Résumé}

Le rapatriement volontaire des réfugiés et des personnes déplacées localement est interprété comme un signe de la restauration de la sécurité et de la stabilité politique, de l'amélioration des relations entre l'état et les citoyens, et d'une augmentation de la confiance dans les efforts de reconstruction des pays déchirés par la guerre. Les résultats présentés dans cet article indiquent que la décision des Irakiens de retourner dans leur pays est moins le résultat d'une meilleure conjoncture en Irak que de leur désir de reconstruire leur vie dans leur pays et de fuir les difficultés légales et socio-économiques qu'ils rencontrent dans les pays voisins. On y explore les expériences des Irakiens qui sont retournés au pays, sur la base des récits de leur retour et de leur ré-émigration en Syrie et en Jordanie. Les micro- et les macro-transformations ayant lieu dans l'Irak d'après Saddam ont en réalité beaucoup de poids sur le retour et la réintégration des réfugiés irakiens dans leur communauté. En absence de solutions durables aux déplacements prolongés, les Irakiens s'engagent dans la mobilité internationale et la recherche de moyens de subsistance, et contribuent ainsi au développement socio-économique de leur pays et des pays voisins par le flux multidirectionnel économique, social et humain qu'ils créent.

\section{Introducing Return and Transnational Mobility in the Iraqi Displacement Context}

The voluntary repatriation of refugees and internally displaced persons (IDPs) is generally interpreted as evidence of progress in a series of post-conflict issues, including restoration of security and political stability, improvements in civilstate relations, and public confidence in reconstruction and development goals in war-torn countries. ${ }^{1}$ In contrast, the protracted presence of displaced populations challenges the legitimacy of post-conflict states. ${ }^{2}$ The findings presented in this article indicate that Iraqi refugees' decision to return is driven less by improvements in the country of origin than by their desire to rebuild their lives back home and to overcome the difficult socio-economic and legal conditions in the countries of first asylum: Syria and Jordan.

The persistent lack of political stability and security in Iraq not only complicates the repatriation of Iraqi citizens but also limits academics' and practitioners' ability to investigate the return experiences of Iraq's forced migrants. This article attempts to address this problem by offering a qualitative study of the experiences of externally displaced Iraqis 
who tried to return and reintegrate into their home societies and who, for a host of reasons, have decided to re-migrate to Syria and Jordan, the neighbouring countries of refuge. Drawing upon the concept of Returnee's Preparedness and Resource Mobilization, ${ }^{3}$ this article defines "return" as an act that entails not only a clear and open choice on the part of the refugee, but, above all, a proof of readiness supported by the gathering of sufficient intangible and tangible resources, indispensable for sustainable reintegration. Iraqis' willingness to return and their resource-mobilization potential, as well as their pre- and post-return conditions, affect their reintegration and their role as agents of social change and development at home. On the other hand, the microand macrotransformations occurring in war-torn Iraq have a strong bearing on the success or failure of refugees repatriations.

The Transnational Mobility and Social Networks ${ }^{4}$ approach is applied here to explore Iraqis' cross-border mobility and networks, which they have developed as alternative livelihood strategies to overcome difficult socioeconomic conditions in the host countries, and the contextual factors that led to their remigration. Refugees' potential role as agents for socio-political and economic development is not solely related to their permanent return. The Iraqi migrants contribute to rebuilding the economic infrastructure and the socio-political fabric of their home country by exposing sending and receiving areas to a constant multidirectional flow of economic and social remittances. ${ }^{5}$ The home and host governments and the international refugee regime have acknowledged the importance of Iraqis' spontaneous cross-border movements and networks. However, they have yet to incorporate them into context-specific return and reintegration assistance policies that maximize the role of returnees and members of the receiving communities as key agents in the national reconstruction process.

\section{Research Methods and Participants}

This study is based on first-hand interviews with Iraqi refugees conducted during a period of field research in Syria and Jordan between January 2010 and March 2011. The discussion is mainly based on Iraqis' accounts of their repatriation and their subsequent remigration. The experiences of Iraqi refugees were observed within the transnational social fields in which they are embedded. Transnational social fields are defined as a set of multiple interlocking networks of social relationships through which ideas, information, goods, practices, and resources are unequally exchanged, organized, and transformed. ${ }^{6}$ Conceptualizing Iraqis' livelihoods as taking place within transnational social fields allows the analysis to expand beyond the refugees in neighbouring countries to those who stayed behind but are connected to them through the networks of social relations, established and sustained across borders. Semi-structured interviews have been conducted with 14 respondents, 7 in Damascus and 7 in Amman. The interviewees have been recruited through a snowballing system: the researcher met participants through friends, colleagues and the UN agencies and NGOs where she worked as a volunteer both in Syria and Jordan. All interviews were conducted in standard Arabic, recorded and translated into English, with the essential support of Arabic-speaking assistants. The sample of participants includes Iraqi individuals and families who:

1. fled Iraq after 2003,

2. are or are not registered with the UNHCR and sought or did not seek resettlement to a third country of asylum,

3. have adopted transnational livelihood strategies,

4. come from any ethno-religious, educational or socioeconomic background,

5. have resided (legally or illegally) in the host country for at least six months, and

6. have returned to any area of Iraq.

The 14 respondents fled between 2003 and 2009, following the US-led invasion and the consecutive escalation of ethno-sectarian violence across the country. Before flight, 11 participants resided in different areas of Baghdad; one in Al-Falluja, Al-Anbar; one in Al-Emara, Misan; one in the city of Basra. Their length of stay abroad varied from six months to over three years. In Damascus research participants were six men, aged between 25 and 68, and a 64-yearold woman. Their level of education varied: five male participants hold university degrees or diplomas, the female participant has a secondary school degree, and the 25-yearold interviewee left Iraq before completing his high school education. In Iraq the female participant was a housewife and the rest of the male participants, with the exception of the student, worked as salaried professionals in schools, universities, and government ministries.

In Amman, respondents were five men, aged between 22 and 63; and two women, aged 30 and 44 years. The five male participants hold university degrees and the two female participants obtained high school diplomas. In Iraq, one of the female participants ran a beauty salon and the other was unemployed; three male participants worked in universities, another male participant owned a supermarket, and the 22-year-old participant was a student. Despite the high educational level among the Iraqis interviewed in Syria and Jordan, only two managed to find regular work opportunities in the host countries, owing to difficulties to obtain work permits. Their well-being depends on transnational kinship ties and other social networks of solidarity and 
financial support, international organizations' cash and inkind assistance, informal work in the local labour market, and migrants' engagement in cross-border income-generating activities between Iraq and the countries of refuge. Mason ${ }^{7}$ correctly highlights how Iraqi refugees' socio-economic circumstances determine their ability to secure legal status and consequently enhance their physical mobility. The inability to freely move across borders reduces migrants' access to resources and opportunities available in Iraq and in other countries, thereby impeding their socio-economic betterment.

The asylum and immigration status of respondents is therefore a key factor influencing their living conditions in exile and their decisions about return. Before repatriation, five participants interviewed in Jordan held an annual residence permit and two had overstayed. Only three of these participants had sought refugee status through the UNHCR. In Syria, all participants held a temporary residence permit, allowing them to travel between the home and the host country. All interviewees met in Damascus were registered with the UNHCR and sought resettlement to a third country of refuge. Holding a valid residence permit was a precautionary measure that allowed them to visit Iraq and re-enter Syria and Jordan at any time, without facing immigration restrictions.

Participants' decision-making processes about return also depended on the religion, socio-cultural values, and gendered power relations in the Iraqi families and communities. With the exception of the female participant from a Christian Chaldean background, the remaining respondents interviewed in Damascus and Amman are Arab Muslims. In Jordan, five respondents are Shiites and two are Sunnites. In Syria one participant is Shiite, three are Sunnites, and the other three Muslim participants refused to disclose their sectarian affiliation, asserting their Iraqi identity and expressing strong disapproval of the ethnosectarian identity politics causing divisions and violence in their home societies. The migratory trajectories of refugees' return and their reintegration experiences have been affected by the phenomenon of ethnically-based territorial and administrative polarization that has forced some participants to abandon their houses and jobs and move from religious and ethnically mixed areas to homogeneous ones in search of safe havens. Among the female participants only one embarked on the migration and return process unaccompanied. The remaining female participants went back with their families and were interviewed in the presence of their husbands, who, conforming to Iraqi sociocultural customs, tended to lead the interview and speak about the return experience on behalf of the whole family. This may have reduced the women's freedom to express their opinions and discuss their personal experiences in greater depth.

The findings presented below are not representative of the entire Iraqi refugee populations in Syria and Jordan or generalizable to other displacement crises. A more comprehensive study of Iraqis' migration experiences and future trends would need a larger sample and greater operational support in the data collection. This article, however, contributes to understanding the complex individual and societal dynamics involved in refugee returns by offering a qualitative analysis of the variety of Iraqi returnees' profiles and experiences. It illustrates how under specific circumstances, Iraqi refugees' transnational livelihoods and social networks have emerged as spontaneous survival mechanisms and opportunities to participate in the economic and sociopolitical developments in Iraq and in their host countries.

\section{Desire to Return and Lack of Alternatives}

The decision to return to areas affected by insecurity and by lack of infrastructure and public services is extremely difficult. Within the limits of available information, legal and socio-economic uncertainty, and constraints in host and home countries, Iraqi refugees evaluate their human conditions and life circumstances and take critical decisions about their future. The participants in this study expressed differing degrees of willingness to return, but, given the absence of security and rule of law in their country, all shared the apprehension that by going back they were exposing themselves to the risk of abuse and violence.

Some participants have fled, alone or with their families, in order to avert becoming victims of the armed conflict and the economic depression associated with it. Their initial intention was to find temporary shelter in neighbouring countries until the situation at home improved and they could return and resume their "normal" lives. Their lack of interest in permanent resettlement in a third country and their greater willingness to return is driven by the lack of family ties abroad. For them, the resettlement experience entails more compromises and losses than advantages: it takes immense courage to travel far from the homeland and rebuild lives from scratch in a different society where migrants are likely to face communication barriers, economic hardships, and socio-cultural integration problems. The high costs and challenges of living in a foreign society combine with migrants' strong desire to reunite with the families and friends whom they have left behind, recoup their lost rights and properties, and resume their pre-war activities in their home communities.

Other participants have left Iraq after being targets of persecution or violence, or witnesses of killings, kidnappings, and forced removal of family members. They attribute 
the gross human rights violations they have suffered to the operations launched by the US-led military forces and the subsequent escalation of politically incited ethno-sectarian violence. The physical abuses they have endured left them with irreversible physical damage, severe burns, disfigurement, scarring, and broken bones. Physical disabilities are aggravated by traumas derived from the tragic loss of loved ones, their houses, land, properties, and jobs. For these refugees return is not a matter of "free choice" but more a reaction to the lack of alternatives. The precarious legal status and means of subsistence in neighbouring countries of asylum, combined with the scarce opportunities for resettlement in the West, have led them to consider return as the only available option. ${ }^{8}$

The lack of progress in resettlement applications is a critical factor in Iraqis' decisions about return. The reluctance of third-party governments in the West to resettle high numbers of refugees, combined with the limited resources and operational capacity of the UN High Commissioner for Refugees (UNHCR) to deal with a substantial amount of resettlement applications, has led to backlogs in the allocation of resettlement places. ${ }^{9}$ In Syria, a number of participants have expressed disappointment and frustration at the UNHCR's delay in examining their refugee files, many of which have been pending for over three years. The long hours spent outside of UNHCR offices, queuing to listen to an overworked UN employee saying "come back in six months, your case is still under scrutiny," crushes their hopes and leaves the migrants in a wearing state of uncertainty about the future. Some have made the decision to go back, overwhelmed by the psychologically and physically challenging living conditions in exile.

In Syria and Jordan, most Iraqis feel trapped in legal and physical limbo. The Syrian Arab Republic and the Hashemite Kingdom of Jordan have not ratified the 1951 Geneva Convention relating to the Status of Refugees. Iraqis are not granted refugee status and are hosted as "temporary guests." Their presence is regulated through temporary residence permits, subject to frequent changes depending on regional and internal politico-economic developments and Syria's and Jordan's relations with the Iraqi government and international donors. In late 2006 Jordan imposed visa restrictions on Iraqi nationals as a result of an increasing fear of a spillover of the sectarian and anti-occupation violence raging in neighbouring Iraq. Syria's imposition of visa requirements on Iraqi refugees in 2007 was less driven by national security concerns than by an attempt by the regime to pressure the US and the Iraqi governments to share the financial burden of the refugee crisis. ${ }^{10}$

The protracted presence of a large number of Iraqi migrants in the two host countries has exerted significant pressures on national infrastructure, water supplies, public services, and housing. The UNHCR has launched several appeals for financial support from developed countries, especially the states directly involved in the 2003 US-led invasion, to assist the Syrian and Jordanian governments to meet the immediate needs of the Iraqi refugees. International financial assistance for the Iraqi refugees hosted in the near abroad has materialized unevenly; Jordan received nearly twice as much as Syria and 1.4 times as much as Lebanon. ${ }^{11}$ The Syrian and Jordanian governments, already struggling to provide basic services and opportunities for their own citizens, have therefore adopted a series of selective policies that discourage Iraqi migrants from integrating permanently into the host societies.

Such policies are driven by host countries' security concerns and calculations of the long-term impact of migrants' presence and cross-border activities on host countries' socio-economic development. The relationship of interdependence between the three neighbouring countries is confirmed by historical bilateral trade and investment agreements in the energy, transit routes, and transportation sectors. ${ }^{12}$ For Syria and Jordan, hosting Iraqi transnational migrants, especially wealthy and powerful Iraqi politicians, businessmen, and merchant families, who have controlled Iraq's agricultural and industrial sectors for the past century, guarantees continued profitable transactions with Iraq. Van Hear has emphasized that involuntary population influxes can bring great benefits to receiving societies in terms of acquisition of human, social, and economic capital needed for local development. ${ }^{13}$ Yet these potential benefits depend upon the existence of a propitious normative environment in the host countries that maximizes the positive impact of migrant capital influx.

In Jordan, Iraqis have to meet stringent requirements such as possessing major in-country investments or currency deposits in local banks to obtain annual residence permits. With the exception of wealthy investors and highly skilled migrants employed in the Jordanian private sector, Iraqi people cannot secure long-term residency and work permits. Those who cannot afford the costs involved in attaining residency overstay their visas and reside irregularly in Jordan. They are subject to accumulative fines and, because of their irregular status, they cannot travel abroad or pay temporary visits to Iraq. The inability to move across borders reduces migrants' access to resources and opportunities available in Iraq or in other countries, thereby causing their socio-economic immobility and downward assimilation in host societies. Since 2008, the Jordanian authorities have granted a number of amnesties to irregular Iraqi residents including the reduction of accumulated fines by 50 percent for those who wish to remain in the country 
and waiving fines for those who wish to return home. It has been reported that these initiatives have been ineffective in augmenting the number of Iraqi returnees ${ }^{14}$ but there are no accurate and independent statistics to verify this claim. Other sources suggest that the unstable security situation at home discourages the Iraqi people's permanent return and there is a widespread perception that once they leave it would be extremely difficult to re-enter Jordan. ${ }^{15}$

The Syrian authorities, in contrast, have granted annual residence permits to members of the Iraqi Ba'th party, traders, businessmen, families with children enrolled in local schools, and highly skilled Iraqis employed in the local labour market. Those who do not belong to these categories possess a permit of stay on humanitarian grounds, valid for three months and renewable, at no cost, at the Immigration and Passports Department. In Syria, as in Jordan, the lack of regular employment and the high costs of investment and higher education opportunities discourage Iraqi families' permanent integration in the host society. Syrian immigration and residency policies towards the Iraqi forced migrants may reflect strategic economic speculations, political calculations against US and international pressures and sanctions, attachment to international financial assistance in a period of economic crisis, and ambitions to deepen political influence and trade relations with Iraq. ${ }^{16}$ Syria's flexible immigration and residency rules are nevertheless facilitating Iraqis' circular movements, their transnational livelihood strategies, their decisions and preparation for return. In contrast, Jordan's more selective regulations have induced many Iraqi migrants into illegality and consequently prevented them from embarking on cross-border movements and activities. Restrictions on Iraqis' freedom of movement across borders hamper their ability to personally assess the situation at home, take decisions, and prepare their sustainable return. ${ }^{17}$

\section{The Preparedness of Iraqi Returnees}

Cassarino $^{18}$ introduces the concept of Returnees' Preparedness which refers to return as a voluntary act that must be supported by the gathering of sufficient intangible and tangible resources to facilitate the sustainable postreturn reintegration experience. The gathering and mobilization of resources prior to repatriation requires time and depends on a number of interconnected variables: migrants' pre-flight circumstances, their living conditions in the host countries, and the available information about return and reintegration challenges and opportunities.

Information about socio-political and economic developments in the areas of return plays a key role in shaping Iraqis' expectations about home and influencing their decisionmaking processes. All the participants in this study obtain information from Iraqi satellite TV channels, phone calls and email exchanges with family and friends in Iraq, visits to and from home areas, and word-of-mouth communications among the Iraqi people living or transiting in the host countries. The Iraqi participants filter the information disseminated by the media and institutional sources since it is perceived as manipulated by competing political forces. The inability of international humanitarian agencies to provide accurate and reliable advice to potential returnees derives from their limited presence and operational capacity in the areas of origin. ${ }^{19}$

In the absence of reliable institutional sources, the participants trust information generated by themselves or by trustworthy informal sources, who produce news oriented towards their own personal concerns. ${ }^{20}$ Refugees' decisionmaking processes are strongly influenced by the available information about conditions in home areas, how it is circulated amongst them, and how they subjectively evaluate and react to it. ${ }^{21}$ The information acquired through these social networks contributes to raising refugees' expectations about their post-return experience. ${ }^{22}$ In some cases, refugees have realized only upon their return that the information obtained by informal sources is less accurate or objective than they expected. The respondents who have not visited Iraq before their repatriation claimed that it is impossible to gather sufficient and accurate information about transformations that have occurred at home during their absence. They feel ill-prepared to plan their return a priori; they need to personally assess the situation at home. The forced migrants who have adopted cross-border livelihood strategies have the opportunity to assess the local realities at home and weigh the costs and benefits of repatriation. Some participants personally witnessed the lack of improvements in their home areas and had low prospects concerning their return experience. Nonetheless, the unsustainable way of life and the lack of stability and future prospects in the host societies had a greater impact on their decision to return than their concerns about the insecurity and political volatility at home.

The personalized information received by Iraqi migrants is only one critical factor influencing their plans and resource mobilization before repatriation. Migrants' preflight circumstances and living conditions in host countries also affect their ability to prepare for return. Before flight, some participants were targets of military operations or ethno-sectarian violence. They were severely injured and lost their loved ones, their houses and jobs. They arrived in the host countries to seek assistance from humanitarian organizations that provide costly and specialized medical care, unavailable in Iraq. Given the losses they have suffered and their struggle to survive in the host countries, they 
have limited potential and independent means to mobilize resources prior to repatriation. The emotional and material losses they endured are inestimable and they have received no compensation for the harms suffered. The sustainable return and reintegration of these migrants requires proactive institutional intervention in the form of effective rep aration schemes that include not only financial and material compensation for damaged and expropriated properties, but also the provision of adequate physical and mental health services and specific rehabilitation programs that offer education and employment opportunities to people with special needs.

Other respondents have not experienced the same degree of violence, destruction, and deprivation before flight. Yet their stay in the host countries is similarly characterized by legal precariousness, lack of employment, and scarce opportunities for socio-economic advancement. In such circumstances, the mobilization of financial and material resources is extremely limited and the migrants rely on available resources at home in order to return and reintegrate. Their well-being depends on money transfers from Iraq and other countries, services subsidized by the host governments, assistance from humanitarian organizations, and casual jobs in the local informal market. In the absence of regular income-generating opportunities in the host societies some refugees have decided to take the risk and return to Iraq, with the expectation to find or resume their old professions and earn wages substantially higher than in neighbouring Syria and Jordan. Post-Saddam Iraq is in a period of high political uncertainty and slow economic growth. In 2008, the Iraqi government granted a large wage increase in the public sector to compensate for the erosion of real wages that had occurred during previous years. ${ }^{23}$ Since mid-2009, oil export earnings have returned to pre-2003 levels and government revenues have recovered and are increasing, along with global oil prices. ${ }^{24}$ Attracted by the news of economic progress, the Iraqi migrants decide to return, despite the difficult security and political circumstances, to earn higher incomes to support their families.

Wealthier and more educated Iraqi families depend on income generated through salaries or state pensions, family businesses, and the income from rents and sales of properties and land in Iraq. The flow of significant financial capital from Iraq allows them to optimize their forced migration experience and turn it into an opportunity to develop and diversify their skills. In Jordan, for instance, some participants have enrolled in higher education programs in local private universities and can afford covering their families' living expenses in the host country for the entire duration of their studies. As long as they are registered students, they are entitled to annual residency permits, granting them freedom to travel to Iraq and to other countries and to engage in cross-border business and other activities. The Iraqis with university degrees and several years of work experience have found a remedy to the lack of employment opportunities in the host countries by working online from home. Some others actively engage in human rights advocacy, fund-raising campaigns, training sessions, and consultancy work, at times in the form of private firms, at others in coordination and partnership with national and international humanitarian organizations, whose field offices are staffed with paid Iraqi volunteers. ${ }^{25}$ Working in such a dynamic and multicultural environment enables them to cultivate social remittances that they invest to promote social change in both sending and receiving countries. Social remittances include enriched individual and collective identities, new ideas, values, behaviours, forms of knowledge, and attitudes towards democracy, human rights, and social justice. ${ }^{26}$ These participants use the material resources at their disposal not only to ensure a safe shelter and the fulfillment of their basic needs but also to acquire qualifications, new skills, and values that they plan to employ to participate in the reconstruction of the economic and social fabric of their country.

In favourable post-return environments, returnees' personal aspirations and their educational and professional advancement may facilitate their reintegration process, their upward social mobility, and their innovative role in their home communities. Some participants have gained consistent financial capital, remittances, transnational business, and social networks which, supported by apposite and well-developed commercial laws, could become the basis for new investments and boost the creation of employment opportunities and economic development in Iraq. ${ }^{27}$ However, the capacity of returnees to invest their assets, skills, and experiences and bring about changes has been affected by the profound socio-political and environmental transformations in the home country. They have had to interact with a new socio-political order in the societies of origin. Adapting to the changing circumstances at home sometimes entailed tough compromises, even forsaking the skills, values, and identities acquired abroad. Those who could not achieve a satisfactory adjustment with the changing conditions at home faced integration challenges and problems and eventually opted for remigration. ${ }^{28}$

\section{Attempting Return and Re-migration from Iraq}

After living in the safety of neighbouring Syria and Jordan for a prolonged period of time, some participants have had difficulties in adapting to the unsafe and poor living conditions in war-torn home areas. Upon return, participants' nostalgic memories of Iraq's beautiful cities and natural 
landscapes have been replaced by images of destruction and dilapidation of historic streets, buildings, and national heritage sites with few visible signs of reconstruction. Some participants described areas of return as "enormous piles of dust and dirt," where high concrete walls and numerous checkpoints hamper people's freedom of movement, divide cities into homogeneous ethno-sectarian areas, and create an atmosphere of fear and suspicion among former neighbours. For some participants, physical reintegration was an exhausting and frustrating process given the unreliable provision of electricity, health care facilities, and other essential public services. They could not bear the general lack of security and the harsh climate and living conditions in their home country. After the end of the "liberation" war, the US Coalition Provisional Authority and the following Iraqi governments disappointed the expectations of Iraqi citizens by neglecting their claim for the right to human rather than military security. ${ }^{29}$ Iraq's transitional period has been characterized by uneven distribution of national resources, socio-economic inequalities, high levels of unemployment and destitution, and a lack of legal protection. These factors caused widespread popular discontent and a growing involvement of Iraqis in conservative religious groups and insurgent movements, which took up the role of alternative guarantors of physical and human security. ${ }^{30}$

Some participants went back to their areas of residence before flight where they own a house, which has not been damaged, expropriated, or occupied by others. They were not afraid of their neighbours; they feared the violence resulting from the power struggle between political parties and their respective militia groups. Others were not able to return to their home areas because their properties have been destroyed or occupied in the course of the episodes of ethno-sectarian cleansing that occurred during the last conflict. The Iraqi mosaic of ethno-religious groups have co-existed in relative peace for centuries and Iraqi families and tribal confederations are the product of inter-ethnic and inter-sectarian marriages. ${ }^{31}$ The pre-1963 Iraqi nationalist movements were cross-ethnic in nature and prioritized domestic development over membership in a supranational Pan-Arab entity. Brigadier Abd al-Karim Qasim (19581963) was the main promoter of a form of inclusive and pluralist Iraqi nationalism. The succeeding Ba'ath regimes endorsed instead a Pan-Arab unity discourse emphasizing a xenophobic and chauvinist interpretation of Arabism that promoted Sunni Arab domination of Iraqi politics and society, repressing Kurdish and Shiite claims to ethno-sectarian self-determination. ${ }^{32}$ Qasim Hussein Saleh ${ }^{33}$ explains that under Saddam Hussein (1968-2003) the Ba'ath regime indoctrinated the people to believe that the Iraqi nation was equivalent to the president or that being loyal to Iraq meant being loyal to Saddam. For over three decades the Iraqi people were exposed to this equation through the state-controlled media outlets, its educational institutions, and its party cadres. When in 2003 the dictator fell and hid in a hole under the ground, Iraqis' feelings of loyalty disappeared with him. After the "big tent" of the state collapsed and law and order turned into chaos, panic spread among the people who divided and sought protection from families, tribes, clans, religious authorities, civil groups, political parties, and any other force or power that could shelter them. The feeling of belonging to the Iraqi nation was suspended and replaced by innumerable loyalties that started competing to achieve a place of authority in the new political power structure. The US Coalition Provisional Authority and the subsequent Iraqi governments enforced constitutional laws and policies such as the 2005 electoral law, the de-Ba'athification order, and the dissolution of the Iraqi national army that reinforced ethno-sectarian divisions and led to the territorial polarization of previously religious and ethnically mixed areas and communities. ${ }^{34}$ The Iraqi society is now struggling to escape a trap set up by foreign powers, local parties, and religious leaders through the political manipulation of ethnic and religious feelings.

For some respondents the relationships with family members and friends who stayed behind has changed along with the surrounding environment. The time spent sheltered in the host countries has offered the forced migrants room to recover from the traumas of the conflict, regain health, learn new things, and look forward to a more hopeful and peaceful future. In contrast, they have depicted their relatives and friends who remained in Iraq during and after the war as "fearful," "worried," "stressed," and prone to suspicious and aggressive behaviours as a response to the multitude of dangers and the depriving living conditions. During the Ba'ath era, there was a single centre of power and social control and Iraqis could recognize and thereby avoid the sources of threats. In contrast, after the fall of the regime, they feel they can no longer guarantee their safety, since they are exposed to unknown perils from several sides. The US military troops, foreign terrorists, and the various political and religious parties ruling the country are ready to use arbitrary force to impose their power and control over national resources. One of the alleged goals of the US-led invasion was to bring democracy and freedom of expression to the Iraqi people. Almost nine years since the end of military operations in Iraq, these objectives have evidently not been achieved. The US disengagement strategy has progressively left the country in the hands of conservative religious authorities and political parties, which repress citizens' freedom of expression and have committed gross human rights violations, including the arrest and 
detention of thousands of civilians without charge and fair trials. ${ }^{35}$ Some participants in this study have remigrated after being subjected to abuses of power committed by the very authorities that were supposed to protect them. One of the returnees owned a supermarket in Baghdad and the local police harassed him and the other shop owners in the area and extorted bribes in exchange for protection. He made the brave decision to report the injustices he was enduring to the governorate authorities. As a result, his shop was destroyed, and he was physically assaulted by security officers and had to escape again from Iraq to protect his family.

Some participants faced difficulties interacting with other members of their home communities, which, during their absence, had become increasingly religious and conservative. After more than four decades of largely secular Ba'athist rule, radical factions in Iraq's Sunnite and Shiite communities have asserted political control over society, leading to the prevalence of conservative religious values and habits such as pressures on women, including Christians, to wear the veil. One of the female returnees was forced out of Iraq for the second time after renewed death threats by a group of unknown armed men, who, the previous year, attacked her because she ran a Haram (forbidden) beauty salon. The assaulters brutally beat her and threw sulphuric acid at her face, causing disfigurement and the loss of one eye. The perpetrators of this horrible act remain at large; the police never opened an investigation into this violent crime.

Other returnees felt neglected by the new Iraqi govern ment, which adopted a series of policies and measures that promoted social inequalities and discrimination rather than national reconciliation and rehabilitation. One of this study's participants returned with his family to Baghdad to reclaim his house, which had been expropriated by members of the new Iraqi National Guard. He was forced to go back to Syria after his failed attempt to seek justice and the restitution of his property. While victims of the former regime have access to mechanisms for land and property rights compensation, ${ }^{36}$ Iraqi victims of land and property rights violations after 2003 have no other option but to seek justice through the ordinary Iraqi court system. They have to go back and file a reclaim with no guarantee of being compensated for the harms suffered. Despite the great need for protection and compensation for their losses, the lack of confidence and mistrust towards public authorities prevents returnee families from registering with the Ministry of Migration and Displacement for reintegration assistance. Afraid of being identified and located by potentially dangerous agents, many returnees avoid state authorities altogether. This type of return and reintegration assistance favours one group over another and is likely to have a negative impact in terms of national reconciliation and peace building since it may sow the seeds for future strife.

The situation of one of this study's participants subject to the Accountability and Justice Law was even more sensitive. He felt he was victim of a grave injustice; the deBa'athification regulations were applied to his case based not on evidence of his individual responsibility but rather on the assumption that being a Ba'ath party member he shared the responsibility for the crimes of the previous regime. As a result, his properties were confiscated, he was forced out of employment, lost his pension rights, and upon return he was again exposed to threats and retribution from elements of the Bader Organization linked to the Shiite Islamic Supreme Council of Iraq (ISCI). The government has used the Accountability and Justice Law as a weapon of collective punishment and a means to eliminate potential agents of dissent or opposition to the newly established political order in Iraq. ${ }^{37}$

Some returnees gave up their rights to social welfare and services from state institutions in order to preserve their dignity and avoid the frustration of dealing with the disorganized and corrupted Iraqi bureaucratic system. In order to obtain support from local authorities some respondents had to pay bribes or use their wastas or personal recommendations and connections with the sectarian political groups, which controlled the various ministries and public offices. The system of patronage and widespread corruption has developed and rapidly proliferated since the 1990s, in reaction to the protracted wars and the devastating effects of the 13 years of UN economic sanctions against Iraq, when state employees received salaries as low as two dollars per month and depended on bribes to sustain their families. Obtaining job opportunities and access to welfare and social protection schemes did not depend on individual needs, qualifications, and skills but on the right connections and affiliations. ${ }^{38}$ Indeed, the change of regime has not brought improvements in this sense. Before, Iraqi people had to be members of one single institution, the Ba'ath party, in order to ensure employment and socio-economic mobility. Now the new ethno-sectarian political order has reshaped the system of patronage into multiple channels of political loyalism that hamper people's rights to equal opportunities. This situation has led one of the interviewees to claim: "Today, corruption is the only institution that can be called national in Iraq; it involves Iraqis from all ethno-sectarian backgrounds and there is coordination between them."

These institutionalized practices prevent the socio-economic reintegration of those who are qualified for certain positions but do not wish to be associated with any religious or political group and refuse to be part of this system of ethno-sectarian discrimination. The participants 
who returned with the intention to actively contribute their knowledge and skills to the national reconciliation dialogue and the reconstruction process have been prevented by the prevailing system and by new threats of persecution and violence. One of the respondents holds a $\mathrm{PhD}$ in political sciences and returned to work in a university in Baghdad. During a conference on the role of religious parties in national politics he made a contribution for which he was assaulted by the outraged audience. After this episode, he had to leave the country and his job again and resettled with his family in Jordan. This experience convinced him that the Iraqi society is not yet ready to offer him an open and democratic work environment, where he can freely express his opinion without fear of subsequent retaliation.

\section{What Happens after Re-migration?}

Under the above mentioned circumstances, these Iraqi migrants' attempts to return were unsurprisingly unsuccessful. Nonetheless, the failed return experiences produced diverse reactions among the research participants. The abortive returns made some lose hope of ever re-establishing their lives back home and have spurred them on to seek onward migration opportunities and an alternative "home" in a Western country, where they hope to achieve personal security, stability, and a better future. After remigration they have resettled temporarily in the neighbouring countries, where they check the progress of their asylum applications with the UNHCR. Some of the respondents employed in Iraqi institutions resigned from their posts, having decided not to return to their old jobs or found more attractive employment opportunities in the host countries' private sector. They have sold their properties in Iraq and invested the money from the sales in houses and businesses in Jordan and Syria. One participant bought two apartments in Amman and has started a car import-export business in collaboration with a network of Iraqi partners based in the US, Jordan, and Iraq. Taking advantage of Jordan's investment promotion laws, the group of investors purchase new cars from the US via the Internet and import them to the Iraqi market through Jordan. Despite their desire to settle permanently in their first countries of asylum and the economic opportunity to do so, the legal and living conditions of Iraqi families in Jordan and Syria are as uncertain as the renewal of their temporary residency permits. Without being granted a longer-term residency status, investing in future projects in the host countries is a hazardous undertaking. The precarious migration status induces the Iraqi families to seek resettlement opportunities in a third country, where they hope to achieve full citizenship rights and long-term integration opportunities.
On the other hand, the challenging post-return experiences in the home areas have not dissuaded some other participants from returning to Iraq. After unsuccessfully seeking compensation for the physical, emotional, and material losses suffered, some participants have re-migrated to Syria and Jordan. However, they keep going back and forth in order to collect assistance from family and friends in Iraq and assess developments at home. They plan a new attempt to return when the situation stabilizes and the Iraqi government enforces the laws and measures necessary to facilitate their safe and dignified repatriation. One participant lives and works in Iraq for roughly two months and then goes back to Damascus to visit his family and bring them the money he earns. Several months after his return to Iraq, another interviewee moved back to Jordan, where he has been offered a $\mathrm{PhD}$ place in a Jordanian private university. His wife and children have permanently resettled in Iraq, where they enjoy the protection and support of their extended families and tribe. Every three months he visits them in Iraq and upon the completion of his doctoral studies he plans to join his family and find work in an Iraqi university. His aspiration is to use the postgraduate qualification and skills he is acquiring in Jordan to contribute to the nation-building process in his country. The former civil servant subjected to the Accountability and Justice Law has found employment in Erbil, in the Kurdistan autonomous region in the north of Iraq, ${ }^{39}$ where he took up a teaching position in a private university. He has embarked on the migration experience alone, while his wife and children have remained in Damascus. These coping mechanisms include refugees' transnational lives, circular migration, and cross-border activities as a livelihood strategy. Nyborg Sørensen ${ }^{40}$ identified two typologies of mobile livelihoods, namely "staggered repatriation" and "revolving returnees." The former includes fragmented families, with one or two members, usually male, returning to the home country in search of socio-economic opportunities, while women and school-age children remain in the country of asylum. Such livelihood strategy is perceived by the migrants as a safety net, since it allows them to reduce the economic and security risks of return. Revolving returnees are instead migrants who plan to return permanently but are forced to re-migrate for economic and security reasons, or due to their failure to reunite with the other members of their families in the country of origin. The information that migrants acquire during their periodic repatriation and the experiences and obstacles they face have a strong impact on their decisions and plans to return permanently.

Before repatriation most respondents do not close their refugee file with the UNHCR since they are uncertain about the security situation at home. In this way, they can go back 
and personally assess conditions in return areas without losing their prima facie refugee status ${ }^{41}$ and the related assistance that they receive in the countries of first asylum. Another precautionary measure adopted by most participants, registered or not with the UNHCR, is renewing their residency permits in the host countries before their departure to Iraq. Holding a valid residency permit allows them to move freely between the home and host countries, without facing immigration restrictions and without being charged expensive entry-visa fees.

The UNHCR has reported these spontaneous cross-border movements: " $[\mathrm{R}]$ ecent increases in no-show rates for food and cash assistance may be an indicator that significant numbers of Iraqis are traveling back and forth to Iraq without deregistering from UNHCR." 42 The agency did not organize 'go and see visits' since a growing number of refugees arrange visits to Iraq by relying on their own means and social networks. The international refugee regime, represented by the UNHCR, has acknowledged the importance of mobility to increase the protection space for Iraqi forced migrants in neighbouring countries. ${ }^{43}$ These policy recommendations, however, have yet to be incorporated in more effective UN-funded assistance programs for the Iraqi refugees and returnees from Syria and Jordan. ${ }^{44}$ In policy and practice the three durable solutions of "resettlement to a third country," "local integration in the first country of asylum," and "voluntary repatriation" are still regarded as discrete options or stages in a refugee "cycle." 45 The governments of Western countries of resettlement consider the Iraqi asylum seekers who have adopted cross-border livelihood strategies less eligible for refugee status. Forced migrants' circular movements reduce their chances to be granted resettlement. The asylum claims of Iraqi circular migrants are dismissed as lacking credibility because it is assumed that the real "refugee" is unable to return to Iraq. Iraqis' return movements are interpreted as an indicator that the circumstances that caused their displacement no longer exist and therefore asylum applicants who engage in transnational mobility should not be treated as refugees but as normal migrants. In interviews with UNHCR resettlement officers, Iraqi asylum seekers are advised not to pay frequent and lengthy visits to Iraq in order to be eligible for resettlement. ${ }^{46}$

The individual case management system set up by the UNHCR in October 2008 to facilitate the Voluntary Assisted Repatriation of Iraqi refugees from Syria and Jordan ${ }^{47}$ is based on the assumption that "returnees" voluntarily reestablish permanent livelihoods in their country of origin. ${ }^{48}$ Accordingly, access to the UNHCR Voluntary Repatriation assistance is conditioned upon (1) the cancellation of beneficiaries' refugee status and the consequent loss of access to the associated international protection and assistance and (2) the cancellation of beneficiaries' residency permit in the host country.

Considering that the Iraqi people engage in cross-border mobility and livelihood strategies to compensate for the insufficient means of subsistence in host countries, and considering that they go back to Iraq under conditions of persistent insecurity, political instability, and slow progress in reconstruction efforts, the assumptions and conditions attached to the UNHCR Voluntary Repatriation Assistance are unrealistic and counterproductive. Instead of supporting refugees' safe and dignified return by protecting their right to free movement and their legal status in the host countries, the Voluntary Repatriation policies increase migrants' legal vulnerability and restrict their ability to move across borders and make informed choices about return.

Not surprisingly, between 2007 and 2011 only 4,479 Iraqi refugees returned facilitated by the UNHCR while the estimated number of unassisted returns in the same period reached 201,307 individuals. ${ }^{49}$ This raises critical questions about dominant understandings and operational approaches to refugee return and transnational mobility. Is return a sedentary and permanent end-state or a process that takes time and entails various degrees and forms of transnational mobility and livelihood strategies? Is it possible to establish absolute and exclusive distinctions between voluntary and involuntary migration? Should the refugees accommodate the bureaucratic categories adopted by the international refugee regime or should institutional approaches be revised to be more responsive to the experiences and needs of forced migrant populations? How do national migration and asylum systems interact with international asylum norms to address the realities of refugee and migrant return and transnationalism?

The UNHCR and some third-party governments discourage Iraqi asylum seekers' circular migration between Iraq, Syria, and Jordan, since this practice hampers national governments' and international organizations' ability to manage highly mobile displaced communities. ${ }^{50}$ A growing number of Iraqi forced migrants nevertheless disregard the institutional requirements and adopt transnational livelihoods as an enduring survival and risk diversification strategy and a way to explore opportunities for the future.

\section{Conclusive Remarks}

The study of Iraqi refugees in Syria and Jordan offers interesting answers to theoretical and empirical questions concerning the relationship between refugees' return and transnational migration. Iraqis' return movements and transnational livelihood strategies are not the product of international multilateral agreements or of regional legal 
refugee protection frameworks. Iraqis are returning despite the limited national and international attention and institutional assistance in their support. Not having signed the 1951 Geneva Convention and having limited resources, the Syrian and the Jordanian governments have incorporated mobility as a key component of their strategic management of the Iraqi protracted displacement. Host authorities' attitudes and migration policies are driven by national security concerns and calculations of the impact of forced migrants' long-term presence and cross-border movements on the socio-economic developments of the home and host societies.

The lack of resettlement opportunities and difficult living conditions in neighbouring countries influence refugees' decision-making processes and migratory plans. Iraqi refugees' return depends on migrants' varying degrees of willingness and readiness to interact with the socio-political and economic transformations occurring in areas of return. The legal and socio-economic obstacles faced in Syria and Jordan limit the ability of forced migrants to mobilize resources before repatriation. Consequently many refugees have to rely on pre-existing resources in order to return and reintegrate in their home areas. The migrants with enough financial and material resources optimize life in exile and turn it into an opportunity to acquire skills and experience that they could employ to facilitate their post-return reintegration and their participation in Iraq's reconstruction.

Iraqis' potential and commitment to return and engage in developments at home is affected by the social, economic, and political changes that have occurred in Iraq during their absence. Repatriation rarely results in the achievement of full citizenship rights. Transitional governments face great challenges and are seldom able, or willing, to grant returning refugees their fundamental rights and freedoms. Post-war economies and receiving communities have limited absorptive capacity to integrate returnees and meet their demands for basic services, employment, and development opportunities. The institutional neglect of the needs and aspirations of the Iraqi returnees increases their vulnerability and threatens the sustainability of their return inducing some to re-migrate.

Refugees' flight, return attempts, and following remigrations are integral and interactive phases of the complex forced migration experience. The protracted wars in Iraq caused progressive fragmentation and global dispersion of Iraqi families and established transnational linkages and practices connecting Iraqi migrants in various countries of the world. In the absence of strong family ties in the home areas, some Iraqis have low motivations and support to re-establish permanent livelihoods in their home communities. Yet they may still wish to return to recoup their lost citizenship rights and properties in order to integrate them into their transnational livelihoods. The international refugee regime is concerned with governing the movement of refugees after repatriation. Stopping returnees' remigration, however, may hamper the natural transnational practices that refugees develop as alternative livelihoods in the absence of other, durable solutions.

\section{Notes}

1. Sarah Petrin, "Refugee Return and State Reconstruction: A Comparative Analysis" (Working Paper 66, New Issues in Refugee Research, UNHCR Evaluation and Policy Analysis Unit, UNHCR, Geneva, 2002).

2. Richard Black, "Conceptions of 'Home' and the Political Geography of Refugee Repatriation: Between Assumption and Contested Reality in Bosnia-Herzegovina," Applied Geography 22 (2002): 123-38; Richard Black and Saskia Gent, "Sustainable Return in Post-conflict Contexts," International Migration 44 (2006):15-38.

3. Jean Pierre Cassarino, "Theorising Return Migration: The Conceptual Approach to Return Migrants Revisited," International Journal on Multicultural Societies 6 (2004).

4. Alejandro Portes, "The Study of Transnationalism: Pitfalls and Promise of an Emergent Research Field," Ethnic and Racial Studies 22 (1999): 217-37; Steven Vertovec, "Conceiving and Researching Transnationalism," Ethnic and Racial Studies 22 (1999): 447-62; Nadje Al-Ali, Richard Black, and Khaled Koser, "The Limits of Transnationalism: Bosnian and Eritrean Refugees in Europe as Emerging Transnational Communities," Ethnic and Racial Studies 24 (2001): 578-600; Geraldine Chatelard, "Jordan as a Transit Country: Semi-protectionist Immigration Policies and Their Effects on Iraqi Forced Migrants" (Working Paper 61, New Issues in Refugee Research UNHCR Evaluation and Policy Unit, UNHCR, Geneva, 2002); Geraldine Chatelard, "A Quest for Family Protection: The Fragmented Social Organization of Transantional Iraqi Migration" (keyote speech to the conference Displacement: Forced Migration in Africa and in the Middle East, British Academy, London, March 28, 2008); Alessandro Monsutti, "Afghan Migratory Strategies and the Three Solutions to the Refugee Problem," Refugee Survey Quarterly 27 (2008): 58-73; Alessandro Monsutti, "The Transnational Turn in Migration Studies and the Afghan Social Networks," in Dispossession and Displacement: Forced Migration in the Middle East and North Africa, ed. Dawn Chatty and Bill Finlayson (Oxford: Oxford University Press, 2010), 45-68.

5. Peggy Levitt, "Transnational Migration: Taking Stock and Future Directions," Global Networks 1 (2001): 195-216; Peggy Levitt and Ninna Nyberg-Sørensen, "The Transnational Turn in Migration Studies” (working paper presented at the Global Commission on International Migration, GCIM). 
6. Ibid., 5 .

7. Victoria Mason, "The Im/mobilities of Iraqi Refugees in Jordan: Pan-Arabism, 'Hospitality' and the Figure of the 'Refugee," Mobilities 6 (2011): 353-73.

8. Gaim Kibreab, "Citizenship Rights and Repatriation of Refugees," International Migration Review 37 (2003): 24-73.

9. Philip Marfleet and Dawn Chatty, "Iraq's Refugees: Beyond Tolerance" (Forced Migration Policy Briefing 4, Refugee Studies Centre, University of Oxford, 2009); Dawn Chatty and Nisrine Mansour, "Unlocking Protracted Displacement: An Iraqi Case Study," Refugee Survey Quarterly 30, no. 4 (2011).

10. International Crisis Group, "Failed Responsibility: Iraqi Refugees in Syria, Jordan, and Lebanon," Middle East Report 77 (2008).

11. Nicholas Seeley, "The Politics of Aid to Iraqi Refugees in Jordan," Middle East Research and Information Project MERIP, Middle East Report Vol. 40, no.256 (Fall 2010). Amnesty International, "Iraq Rhetoric and Reality: The Iraqi Refugee Crisis" (30/08/2011), http://www.amnesty.org /en/library/asset/MDE14/011/2008/en/43d61 ea9-3637 -11dd-9db5-cb00b5aed8dc/mde140112008eng.pdf; International Crisis Group, "Failed Responsibility: Iraqi Refugees in Syria, Jordan and Lebanon," Middle East Report 77 (2008).

12. Laurie A.Brand, "Economics and Shifting Alliances: Jordan's Relations with Syria and Iraq, 1975-81," International Journal of Middle East Studies 26, no. 3 (August 1994): 393-413.

13. Nicholas Van Hear, "The Impact of the Involuntary Mass 'Return' to Jordan in the Wake of the Gulf Crisis," International Migration Review, vol. 29, no. 2 (Summer 1995): 352-74.

14. Integrated Regional Information Networks, “Jordan: Visa fine waiver not enough to lure Iraqis home" (30/08/2011), http://www.unhcr.org/refworld/docid/47bea841c.html.

15. Author's interview with Jordanian Legal Aid firm staff.

16. Ibid., 9 .

17. Geraldine Chatelard, "Cross-Border Mobility of Iraqi Refugees," Forced Migration Review 34: 60-61 (2010).

18. Jean Pierre Cassarino, Tunisian New Entrepreneurs and Their Past Experiences of Migration in Europe: Resource Mobilization, Networks, and Hidden Disaffection (Aldershot: Ashgate, 2000).

19. Jeff Crisp, Jane Janz, Jose Riera, and Shaira Samy, "Surviving in the City. A Review of UNHCR's Recent Experience in Relation to Iraqi Refugees in Urban Areas of Jordan, Lebanon and Syria" (Geneva: UNHCR Policy Development and Evaluation Service, 2009).

20. Martha Walsh, Richard Black, and Khaled Koser, "Repatriation from the European Union to Bosnia Herzegovina: The Role of Information," in The End of the Refugee Cycle?: Refugee Repatriation and Reconstruction, ed. R. Black and K. Koser (New York: Berghahn Books, 1999).
21. Khaled Koser, "Repatriation and Information: A Theoretical Model, " in Geography and Refugees: Patterns and Processes of Change, ed. Richard Black and Vaughan Robinson (London: Belhaven, 1993); Khaled Koser, "Information and Repatriation: The Case of Mozambican Refugees in Malawi," Journal of Refugee Studies 10 (1997): 1-17.

22. David Turton and Peter Marsden, “Taking Refugees for a Ride? The Politics of Refugee Return to Afghanistan" (report for the Afghanistan Research and Evaluation Unit (AREU), funded by the European Commission Humanitarian Aid Office (ECHO, 2002).

23. International Monetary Fund, "Iraq: Staff Report for the 2009 Article IV Consultation and Request for Stand-By Arrangement", Country Report N. 10/72, (Washington DC: IMF Publication Services, March 2010).

24. Ibid., 9 .

25. Geraldine Chatelard, "Deferred Involvement: Memories and Praxes of Iraqi Intellectuals as Civil-Society Activitists between Iraq, Jordan and Syria" (paper presented at the workshop Memories of Iraq, University of Maryland, College Park (1-2 May 2009); Geraldine Chatelard, "What Visibility Conceals: Re- embedding Refugee Migration from Iraq", in Dispossession and Displacement: Forced Migration in the Middle East and North Africa, ed. Bill Finlayson and Dawn Chatty ( New York: Oxford University Press, 2010).

26. Ibid., 5 .

27. Robyn Iredale, Fei Guo, and Santi Rozario, Return Migration in the Asia Pacific (Cheltenham: Edward Elgar, 2003); Lynellyn Long and Ellen Oxfeld, Coming home? Refugees, Migrants and Those Who Stayed Behind (Philadelphia: University of Pennsylvania Press, 2004).

28. Ibid., 13.

29. Bahgat Korany, "National Security in the Arab World: The Persistence of Dualism," in D. Tschirgi ed. "The Arab World Today" (Boulder, CO: Lynne Rienner, 1994). Sultan Barakat, After the Conflict: Reconstruction and Development in the Aftermath of War (London: I.B.Tauris, 2005).

30. Benjamin MacQueen and Shahram Akbarzadeh, "Islamic Reformism and Human Rights in Iraq: Gender Equality and Religious Freedom," in "Islam and Human Rights in Practice: Perspectives across the Ummah," ed. Benjamin MacQueen and Shahram Akbarzadeh (London: Taylor and Francis, 2008); Bruce R. Pirnie and Edward O'Connell, "Counterinsurgency in Iraq (2003-2006)," RAND Report (30/08/2011), http://insurgencyresearchgroup.wordpress .com/2008/03/13/counterinsurgency-in-iraq/.

31. Hanna Batatu, The Old Social Classes and the Revolutionary Movements of Iraq: A Study of Iraq's Old Landed and Commercial Classes and of Its Communists, Baiathists and Free Officers (New Jersey: Princeton University Press, 2004).

32. Eric Davis, "History Matters: Past as Prologue in Building Democracy in Iraq," Orbis 49 (2005): 229-44; Martin Bunton, "From Developmental Nationalism to the End of 
Nation- State in Iraq?” Third World Quarterly 29 (2008): 631-46.

33. Qasim Hussein Saleh, "The Iraqi Society: A Psychosociological Analysis of What Happened and Happens" [Amman, Jordan: Al-Majlis Al-Iraqi lil-Thaqafa (The Iraqi Cultural Council) and Arab Scientific Publishers, 2008; original text in Arabic]

34. Alex J. Bellamy, "Ethics and Intervention: The 'Humanitarian Exception' and the Problem of Abuse in the Case of Iraq," Journal of Peace Research 41 (2004): 131-47; Nina Caspersen, "Good Fences Make Good Neighbours? A Comparison of Conflict-Regulation Strategies in Postwar Bosnia," Journal of Peace Research 41 (2004): 569-87; Patrick Cockburn, The Occupation: War and Resistance in Iraq (London: Verso, 2006); International Crisis Group, "Iraq: Don't Rush the Constitution," Middle East Report 42 (June 2005); International Crisis Group, "Unmaking Iraq: A Constitutional Process Gone Awry” (Middle East Policy Briefing 19, September 2005); International Crisis Group, "The Next Iraqi War? Sectarian and Civil Conflict" Middle East Report 52 (February 2006).

35. Amnesty International, "Iraq: Broken Bodies, Tortured Minds: Abuse and Neglect of Detainees in Iraq" (19/04/2012), http://www.amnesty.org/en/library/asset /MDE14/001/2011/en/48c3c6e6-9607-4926-abd7 -d1da1c51a976/mde140012011en.pdf.

36. Peter Van der Auweraert, "Land and Property Issues in Iraq: Present Challenges and Future Solutions,", in Resolving Iraqi Displacement: Humanitarian and Development Perspectives, The Brookings Institution-University of Bern Project on Internal Displacement (Washington, DC: Brookings Institution, 2009), 27-39.

37. Miranda Sissons, "Iraq's New Accountability and Justice Law” (briefing paper, International Centre Transitional Justice, New York, 2008).

38. Anthony Arnove and Ali Abunimah, Iraq under Siege: The Deadly Impact of Sanctions and War (London: Pluto, 2000).

39. For a closer analysis of Iraqi-Kurdish relations and the related patterns of internal displacement and migration governance, see Denise Natali, "The Kirkuk Conundrum" Ethnopolitics [formerly Global Review of Ethnopolitics] 7, no. 4 (2008): 433- 443; David Romano, "Whose House Is This Anyway? IDP and Refugee Return in Post-Saddam Iraq," Journal of Refugee Studies 18 (2005): 430-53; Philip Marfleet, "Displacement and Denial: IDPs in Today's Iraq," International Journal of Contemporary Iraqi Studies 5, no. 2 (2011): 277-92.

40. Levitt and Nyberg-Sørensen, "The Transnational Turn in Migration Studies."

41. In 2009 the UNHCR issued the new "Eligibility Guidelines for Assessing the International Protection Needs of Iraqi
Asylum Seekers." The main amendment to the 2007 Guidelines is that due to improvements in the security situation in some Iraqi regions the international protection needs of asylum seekers from the governorates of Babel, Basrah, Diwaniyah, Kerbala, Missan, Muthanna, Najef, Thi-Qar, and Wassit, and from Al-Anbar governorate should be assessed on an individual instead of on a prima facie basis.

42. UNHCR,(Iraq fact sheet January 2009.

43. Jane Janz, Jose Riera, and Shaira Samy, "Surviving in the City: A Review of UNHCR's Recent Experience in Relation to Iraqi Refugees in Urban Areas of Jordan, Lebanon and Syria" (Geneva: UNHCR Policy Development and Evaluation Service, 2009).

44. Ibid., 17; Katy Long, "Home Alone? A Review of the Relationship between Repatriation, Mobility and Durable Solutions for Refugees" (policy paper for the UNHCR Policy Development and Evaluation Service (PEDES), Geneva: UNHCR, 2010).

45. Nicholas Van Hear, "Refugees in Diaspora: From Durable Solutions to Transnational Relations," Refuge 23 (2006); Jeff Crisp and Katy Long, "Migration, Mobility and Solutions: An Evolving Perspective," Forced Migration Review 35 (2010).

46. Interview by the author of UNHCR Protection Officers.

47. The UNHCR does not promote voluntary repatriation and maintains its position that due to persisting insecurity concerns and to the slow progress in reconstruction efforts, conditions in Iraq are still not conducive to large-scale refugee returns. However, faced with increasing spontaneous return movements from neighbouring countries of asylum, in 2008 the UN agency has started a Voluntary Repatriation Programme (VRP) based on an individual case management system, which facilitates the return of Iraqis who, despite the insecurity and political instability, wish to return to their places of origin.

48. Briefing Points Regarding the UNHCR Assistance Framework for Voluntary Repatriation to Iraq.

49. UNHCR Iraq Monthly Statistical Update on Return-January 2012, (19/04/2012), http://reliefweb.int/node/480435.

50. Interview by the author of UNHCR Senior Protection Officers.

Vanessa Iaria is a PhD candidate in migration studies at the University of Sussex, Brighton. The fieldwork for this research project was conducted with the kind support of the Council for British Research in the Levant and the British Institute for the Study of Iraq. 
(C) Vanessa Iaria, 2011. This open-access work is licensed under a Creative Commons Attribution-NonCommercial 4.0 International License, which permits use, reproduction and distribution in any medium for non-commercial purposes, provided the original author(s) are credited and the original publication in Refuge: Canada's Journal on Refugees is cited. 